Pugh was appointed to the chair at the Victoria University of Manchester, and for many years he has taken a prominent part in university administration in the office of deputy vice-chancellor. In 1948 he served on a commission appointed to consider proposals for a University of Malaya, and in 1949 he was president of Section C of the British Association. He has served on the Council of the Geological Society during 1933-38 and from 1947 to date and was a vice-president during 1936-38. Prof. Pugh's researches and published works have been mainly on the Lower Palæozoic rocks of central and north Wales, and in recent years he has been engaged, in collaboration with Prof. O. T. Jones, in a detailed survey on the 25-inch scale of the Ordovician rocks of central Wales near Builth and Llandrindod. This is probably the largest area anywhere to be surveyed geologically on this scale.

\section{Sir Wilson Jameson, G.B.E., K.C.B.}

THE office of chief medical officer of the Ministries of Health and Education follows in direct line of descent that of Medical Officer of the Privy Council created in 1858 and first filled by Sir John Simon. Since the Ministry of Health was formed in 1919 there have been only three chief medical officers: Sir George Newman, Sir Arthur MacNalty and Sir Wilson Jameson, the last of whom reached the retirement age on May 11. $\mathrm{H}_{\theta}$ is a graduate of Aberdeen, and his main work before he became a Civil Servant had been as dean of, and professor of public health in, the London School of Hygiene and Tropical Medicine. Following a short period as medical adviser to the Colonial Office, he was appointed to his present position in 1940. He was faced at once with problems of great magnitude, as failure in the health services would have had a far-reaching effect on the successful conduct of the War. London and other large industrial cities were being subjected to heavy aerial bombardment, shelter life carried the risk of grave epidemic disease, the evacuation of children presented many medical problems, and added to all this was the ever-present threat to our food supply. He gave sound advice on all these matters. $\mathrm{He}$ inaugurated the highly successful national campaign for immunization against diphtheria. His broadcasts on this subject made his name a household word. He broke the taboo against the mention of venereal disease in newspapers and on the radio. His interest in medical education led to the appoint. ment of the Goodenough Committee on this subject and the subsequent adoption of its main recommendations by the Government, with the consequent great increase in the money made available to, and by, the University Grants Committee. He played an active part in the inauguration of the National Health Service, and though opinions differ on the details of the scheme there is no dispute as to the excellence of the principles which underlie it. It is no doubt due to Sir Wilson's advocacy that the teaching hospitals in England and Wales have been allowed to retain their endowments and that each has its own Board of Governors responsible direct to the Ministry of Health. Among Sir Wilson's many honours are G.B.E., K.C.B., Harveian Orator of the Royal College of Physicians, Buchanan Medal of the Royal Society, a Lasker Award of the American Public Health Association, and many honorary degrees. . His departure from the Ministries of Health and Education will be greatly regretted. The seeds which he has sown there will bear fruit in plenty for many years to come. His wealth of experience is such that the King Edward Fund is to be congratulated warmly on having secured his part-time services.

\section{Systematic Botany at Kew}

THE Herbarium and Library of the Royal Botanic Gardens, Kew, were open to members of scientific societies on May 5 and to students from universities and colleges on May 6. A large series of exhibits and demonstrations were arranged by members of the Kew staff to illustrate two main themes: research work in progress at Kow, and the methods and principles of plant taxonomy. The ground-floors of three wings of the Herbarium were occupied by beautifully arranged specimens of living and preserved plants, drawings, paintings, diagrams and photographs. In the Library there were displayed selected books and periodicals illustrating Kow publications and the use to which a specialized library is put in taxonomic research.

On May 5, Dr. N. L. Bor, assistant director, and Dr. W. B. Turrill, keeper of the Herbarium and Library, welcomed visitors and explained the main purposes of the exbibition. On May 6, Sir Edward Salisbury, director, opened the proceedings with an account of the history of Kow as a scientific establishment and of the researches now being carried out in the several departments. More than $\mathbf{4 5 0}$ guests were received on the two days. Among special exhibits were those illustrating the great range of leaf structure in grasses, the evolution of the genus Rhododendron, new or interesting South American plants, the flora of Iraq, geocarpy, a new classification of the sedges, varieties of ivy, variation in cedars, monographic work on Basidiomycetes and on West Indian Fungi, methods of determining Fungi, ferns of special interest, Australian Gleicheniaceæ, tropical Algæ, seeds of economic interest, and different kinds of manna.

A demonstration of the "birth of a family" attracted much attention. It illustrated the affinities of a tall forest tree, recently collected, by a member of the Kew staff, in the Cameroons. This represents an entirely new family which it is difficult to place satisfactorily in existing systems of classification. Prominence was given to the great new work on the flora of Tropical East Africa which has been commenced at Kew for the Colonial Office. This is to be an illustrated systematic account of all the known vascular plants from Uganda, Kenya, Tanganyika and Zanzibar - an estimated total of 10,000-12,000 species. It will take many years to complete and will involve much investigation both at Kew and in East Africa. One wing of the Herbarium was occupied by a unique series of exhibits designed to demonstrate to students and teachers the practical methods and theoretical principles of taxonomic research. These were shown to involve or include the assembly of material for study, the recognition of characters of systematic value, the investigation of taxonomic groups, and various problems encountered in the course of research.

\section{Electrical Machine Analysis}

A COLLOQUTUM on electrical machine analysis was held in the Electrical Engineering Department of the Imperial College of Science and Technology, London, during April 3-4. It was attended by some forty engineers, drawn from industry, the universities and technical colleges, who met to discuss progress in the development of methods of analysis for determ- 